\title{
0995. Aspirin reduces neutrophilic pulmonary inflammation in a human model of acute respiratory distress syndrome induced by inhaled lipopolysaccharide
}

\author{
U Imran Hamid*, J Conlon, S Spence, A Krasnodembskaya, A Kissenpfennig, DF McAuley, CM O'Kane
}

From ESICM LIVES 2014

Barcelona, Spain. 27 September - 1 October 2014

\section{Introduction}

Acute respiratory distress syndrome (ARDS) is characterized by damage to the alveolar epithelial-endothelial barrier resulting in neutrophil influx and pulmonary oedema. The activation of platelet and secondary capture of neutrophils may play an important role in propagation of inflammation in ARDS [1]. Various animal studies have shown that aspirin therapy reduces pulmonary oedema and development of lung injury [2]. In observational studies, patients on aspirin therapy prior to hospital admission had a reduced incidence of ARDS [3]. By acetylating cyclooxygenase, aspirin inhibits platelet aggregation and generates anti-inflammatory molecules which modulate neutrophilic inflammation [4].

\section{Objective}

To test the hypothesis that aspirin reduces pulmonary inflammation in an in vivo human model of acute respiratory distress syndrome, induced by inhaled lipopolysaccharide (LPS).

\section{Methods}

Healthy subjects were enrolled in a double-blind, placebo-controlled study and were randomised to receive aspirin $75 \mathrm{mg}$ or aspirin $1200 \mathrm{mg}$ or placebo (1:1:1) for seven days prior to LPS inhalation. Measurements were performed in bronchoalveolar lavage (BAL) fluid obtained at 6 hours after inhaling 50 micrograms of LPS.

\section{Results}

33 healthy subjects were enrolled. There was no significant difference between aspirin $75 \mathrm{mg}$ and aspirin $1200 \mathrm{mg}$. Data for both aspirin groups were combined. Aspirin pre-treatment reduced LPS induced BAL neutrophilia (figure 1) and BAL concentrations of both the neutrophil-specific protease MMP-8, and the pro-inflammatory cytokine TNF- $\alpha$. There was a non-significant trend towards reduction in a range of inflammatory cytokines (table 1).

Figure 1: Aspirin reduces LPS induced BAL neutrophilia.

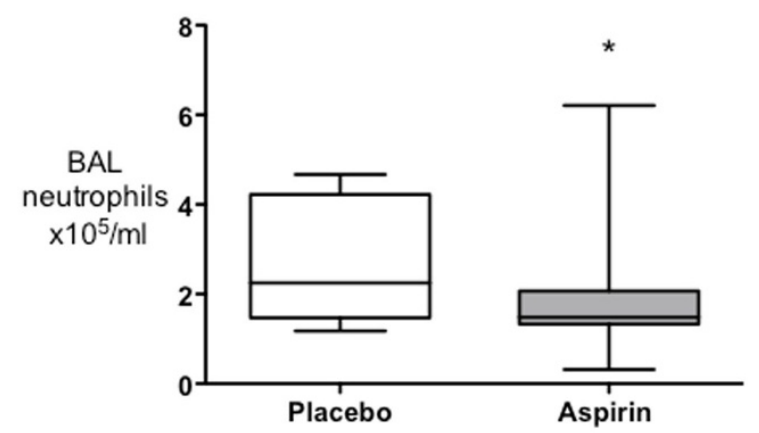

$$
\mathrm{p}=0.03
$$

Figure 1 Aspirin reduces LPS induced BAL neurtophilia.

\section{SpringerOpen $^{\circ}$}

(c) 2014 Hamid et al; licensee Springer. This is an Open Access article distributed under the terms of the Creative Commons Attribution License (http://creativecommons.org/licenses/by/2.0), which permits unrestricted use, distribution, and reproduction in any medium, provided the original work is properly cited. 
Table 1 Effect of aspirin on markes of pulmonary inflammation

\begin{tabular}{|c|c|c|c|c|}
\hline \multicolumn{5}{|l|}{$\mathrm{BAL}$} \\
\hline & Placebo $(n=13)$ & Aspirin $(n=20)$ & $\%$ reduction & $\mathrm{p}$-value \\
\hline PMN (10 cells/ml) & $2.25(1.18,4.67)$ & $1.48(0.32,6.21)$ & 34.2 & 0.03 \\
\hline$\overline{T N F-\alpha(p g / m l)}$ & $105.7(73.49,358.5)$ & $79.72(37.34,276.6)$ & 24.5 & 0.02 \\
\hline IL-6 (pg/ml) & $856.5(535.9,2285)$ & $647.9(224.6,1582)$ & 24.1 & 0.07 \\
\hline MMP-8 (pg/ml) & $6342(1932,9574)$ & $2902(862.8,6758)$ & 54 & 0.03 \\
\hline MMP-9 (pg/ml) & $48493(23126,99780)$ & $33717(10471,72334)$ & 30.4 & 0.03 \\
\hline IL-8 (pg/ml) & $447.5(236.9,1250)$ & $345.9(175.5,1522)$ & 22.7 & 0.11 \\
\hline $\mathrm{IL}-1 \beta(\mathrm{pg} / \mathrm{ml})$ & $42.74(25.98,98.76)$ & $37.03(18.73,54.88)$ & 13 & 0.16 \\
\hline
\end{tabular}

\section{Conclusion}

This study shows for the first time that aspirin can reduce neutrophilic inflammation in the lung in humans. Further clinical studies are warranted to assess its ability to reduce neutrophil mediated inflammation in ARDS.

\section{Grant acknowledgement}

This work was funded by the UK Intensive Care Society.

ClinicalTrials.gov identifier: NCT01659307.

Published: 26 September 2014

\section{References}

1. Kuebler WM: J Clin Invest 2006, 116(12):3106-8.

2. Looney MR, et al: J Clin Invest 2009, 119(11):3450-61.

3. Erlich JM, et al: Chest 2011, 139(2):289-95.

4. Filep JG, et al: Prostaglandins Leukot Essent Fatty Acids 2005, 73(3-4):257-62.

Cite this article as: Hamid et al:: 0995. Aspirin reduces neutrophilic pulmonary inflammation in a human model of acute respiratory distress syndrome induced by inhaled lipopolysaccharide. Intensive Care Medicine Experimental 2014 2(Suppl 1):P80.

\section{Submit your manuscript to a SpringerOpen ${ }^{\mathcal{O}}$ journal and benefit from:}

- Convenient online submission

- Rigorous peer review

- Immediate publication on acceptance

- Open access: articles freely available online

- High visibility within the field

- Retaining the copyright to your article 